\title{
HJC, a New Arylnaphthalene Lignan Isolated From Justicia procumbens, Causes Apoptosis and Caspase Activation in K562 Leukemia Cells
}

\author{
Jiaoyang Luo ${ }^{1}$, Weijun Kong ${ }^{1}$, and Meihua Yang ${ }^{1, *}$ \\ ${ }^{1}$ Institute of Medicinal Plant Development, Chinese Academy of Medical Sciences and Peking Union Medical College, \\ Beijing 100193, P.R. China
}

Received October 22, 2013; Accepted March 30, 2014

\begin{abstract}
The aim of this study is to investigate whether HJC, isolated from Justicia procumbens for the first time, can suppress the proliferation and induce apoptosis of human leukemia K562 cells and finally clarify its related mechanism. The chemical structure of $\mathrm{HJC}$ was validated by LC-ESI-MS/MS, cytotoxicity was assayed using MTT, and apoptosis was investigated by flow cytometry. These assays indicated that HJC remarkably inhibited the growth in K562 cells by decreasing cell proliferation, reducing the SOD activity, enhancing ROS levels and inducing apoptosis. Activation of caspase-3 indicated that HJC may be inducing intrinsic and extrinsic apoptosis pathways and that HJC-induced apoptosis was caspase-dependent. This study suggests that $\mathrm{HJC}$ is a high-potency anti-tumor agent, and it induces apoptosis through a caspase-dependent pathway in human leukemia K562 cells. It also presents a potential alternative to leukemia therapy.
\end{abstract}

Keywords: 6'-hydroxy justicidin C, LC-ESI-MS/MS, apoptosis, SOD activity, caspase-dependent pathway

\section{Introduction}

Numerous efforts have been made to search for effective agents against cancer, in particular from herbal medicines. Deoxypodophyllotoxin and podophyllotoxin (POD) are two well-known naturally occurring aryltetralin lignans. Both compounds are cytotoxic (1), and their derivatives such as etoposide (ETO) $(2,3)$, teniposide (4), and etopophos have potential clinical use as antitumor agents $(5,6)$. However, due to the drug resistance developed by cancer cells as well as side effects associated with the use of these agents in the clinic (including myelosuppression, neutropenia, and nausea), the search for new effective anticancer analogs remains an intense area of research $(7,8)$.

Justicia procumbens (J.procumbens) is a traditional herbal remedy used to treat fever, pain, and cancer (9). The bioactive justicins isolated from $J$. procumbens in the past few years included diphyllin, 6'-hydroxy

*Corresponding author. yangmeihua15@hotmail.com Published online in J-STAGE

doi: 10.1254/jphs.13211FP justicidin A (HJA), and chinensinaphthol methyl ether (CME), which each have a chemical structure similar to that of POD $(10-12)$. These justicins were proved to have a wide spectrum of biological activities, such as cytotoxicity $(13-15)$, antimicrobial (16), anti-platelet (17), and antiviral activities (18). A new justicin 6'hydroxy justicidin $\mathrm{C}$ (HJC) was for the first time isolated from $J$. procumbens. To date, there have been no reports about the therapeutic activity of HJC and how it mediates its anti-cancer effect.

Mitochondria play a central role in various pathophysiological processes of cancer cells, in particular apoptosis. Most anti-tumor drugs can induce apoptosis in different types of tumor cells. There are two major apoptotic pathways known to date - the intrinsic pathway and the extrinsic pathway, which both result in activation of effector caspases as the final step. The intrinsic apoptotic pathway involves an increase in mitochondrial membrane permeability and an increased release of cytochrome $c$ into the cytoplasm, which in turn activates caspase-9 and caspase-3, resulting in apoptotic damage $(19,20)$. The extrinsic pathway is initiated by the activation of death receptors that involves the formation of a death- 
inducing signaling complex (DISC). DISC formation results in the activation of caspase- 8 , which activates caspase-3 (21).

In the present study, we investigated whether HJC could modulate the survival and proliferation of cancer cells. Our on-going research indicated that HJC was cytotoxic against various tumor cells, and human leukemia K562 cell line was one of the most sensitive cell lines to the anti-tumor effect of HJC. In addition, the activity of HJC on several cell lines was better than that of HJA and CME. Therefore, in the present study, we further illustrate whether HJC treatment can induce apoptosis and clarify the related mechanism of HJC.

\section{Materials and Methods}

\section{Materials}

POD, ETO, and paclitaxel (TAX) were purchased from Sigma (St. Louis, MO, USA). HJC was isolated from $J$. procumbens and identified by UV, IR, and ${ }^{1} \mathrm{H}$ and ${ }^{13} \mathrm{C}$-NMR $(12,22)$. The cycle TEST ${ }^{\mathrm{TM}}$ PLUS DNA reagent kit, FITC active caspase-3 apoptosis kit, and FITC Annexin V apoptosis detection kit were purchased from BD Pharmingen (San Diego, CA, USA). The SOD activity assay kit was purchased from Nanjing Jiancheng Bioengineering Institute (Nanjing, China).

HJA and HJC were obtained by the following procedures: The dried plant $(5 \mathrm{~kg})$ of $J$. procumbens was extracted with hot $95 \%$ ethanol, 3 times successively. After removal of the solvent by evaporation, the residue was suspended in water and defatted with petroleum ether. The aqueous layer was further extracted with ethyl acetate. The resulting ethyl acetate extract ( $68 \mathrm{~g}$ ) was subjected to silica gel $\mathrm{CC}$ using the chloroformmethanol system $(100: 0$ to $2: 1)$ to yield 70 fractions. Fractions 23-26 (3 g) were combined and subjected to $\mathrm{CC}$ on silica gel, Sephadex LH-20 gel, followed by preparative reverse-phase $\mathrm{C}_{18}$ HPLC using an acetonitrilewater system (30:70 to 40:60) to yield compounds HJA (pale yellow amorphous powder, $30 \mathrm{mg}$ ) and HJC (pale yellow amorphous powder, $8 \mathrm{mg}$ ) (12).

\section{LC-MS/MS validation}

The UHPLC system consisted of an LC-20AD pump, a DGU-20 A3 degasser, an SIL-20AC autosampler and a CTO-20A column oven (Shimadzu, Kyoto). The UHPLC separation was performed on an Agilent Extent- $\mathrm{C}_{18}$ column $(2.1 \mathrm{~mm} \times 50 \mathrm{~mm}, 1.8 \mu \mathrm{m})$ with a gradient elution by a mobile phase consisting of $0.1 \%$ formic acid aqueous solution (A) and acetonitrile (Fisher, USA) with $0.1 \%$ formic acid (B) with the following gradient: $0.01-2.00 \mathrm{~min}$, linear from $80 \% \mathrm{~A} / 20 \% \mathrm{~B}$ to $60 \%$ A / 40\% B; $2.00-4.00$ min, linear from $60 \%$ A / 40\% B to $55 \% \mathrm{~A} / 45 \% \mathrm{~B} ; 4.00-7.00 \mathrm{~min}$, linear from $55 \%$ $\mathrm{A} / 45 \% \mathrm{~B}$ to $52 \% \mathrm{~A} / 48 \% \mathrm{~B} ; 7.00-9.00 \mathrm{~min}$, linear from $52 \% \mathrm{~A} / 48 \% \mathrm{~B}$ to $50 \% \mathrm{~A} / 50 \% \mathrm{~B} ; 9.00-9.01$ min, switch from $50 \% \mathrm{~A} / 50 \% \mathrm{~B}$ to $80 \% \mathrm{~A} / 20 \% \mathrm{~B}$; and hold $80 \% \mathrm{~A} / 20 \% \mathrm{~B}$ until $10.00 \mathrm{~min}$. The injection volume was $4 \mu \mathrm{l}$. The UHPLC system was coupled with an API 5500 Qtrap mass spectrometer (Applied Biosystems/MDS Sciex, Concord, ON, Canada) via a Turbo IonSpray ionization interface. Following optimization of the setting parameters, the instrument was operated in the positive mode with an ion spray voltage of $5.5 \mathrm{kV}$, curtain gas pressure of $35 \mathrm{psi}$, nebulizer gas pressure of $50 \mathrm{psi}$, heater gas pressure of $50 \mathrm{psi}$, and the source temperature set at $550^{\circ} \mathrm{C}$. The curtain, nebulizer, heater, and collision gases were all nitrogen. The multiple reaction monitoring (MRM) conditions were $\mathrm{m} / \mathrm{z} 411.1 \rightarrow 362.9, \mathrm{~m} / \mathrm{z} 411.1 \rightarrow 381.5$. The declustering potential (DP), collision cell exit potential (EXP), and collision energy (CE) was $90 \mathrm{~V}, 13 \mathrm{~V}$, and $30 \mathrm{~V}$, respectively. The data were collected and analyzed by the Analyst Data Acquisition and Processing software (Version 1.6; Applied Biosystems, Foster City, CA, USA).

\section{Cell cultures}

Human leukemia K562, human promyelocytic leukemia HL-60, mouse lymphocytic leukemia L1210, and P388D1 mouse macrophage cell lines were obtained from Cancer Institute \& Hospital, Chinese Academy of Medical Sciences. The cell lines were cultured in RPMI-1640 (GIBCO BRL, Grand Island, NY, USA) medium containing $10 \%$ heat-inactivated fetal bovine serum, $100 \mathrm{U} / \mathrm{ml}$ penicillin, and $100 \mathrm{U} / \mathrm{ml}$ streptomycin. Cells were maintained at $37^{\circ} \mathrm{C}$ in an atmosphere of $5 \%$ carbon dioxide- $95 \%$ air.

\section{Cell viability assay and morphological evaluation}

Cytotoxicity was determined using a modified 3(4, 5-dimethylthiazol-2-yl)-2, 5-diphenyltetrazolium bromide (MTT) colorimetric assay (23). HJC was dissolved in dimethylsulfoxide (DMSO; Sigma, St. Louis, MO, USA) and the final concentration of DMSO was $0.1 \%(\mathrm{v} / \mathrm{v})$. DMSO $(0.1 \%)$ without HJC was used as the control. HJC was added to the culture medium at different final concentrations, which ranged from 0.13 to $135 \mu \mathrm{M}$. Cells on 96-well plates (Nunc, Roskilde, Denmark), at an initial density of $1 \times 10^{5}$ cells $/ \mathrm{ml}$, were treated with different concentrations of the test agent for $48 \mathrm{~h}$. After addition of $20 \mu \mathrm{l} \mathrm{MTT}(5 \mathrm{mg} / \mathrm{ml}$; Sigma, St. Louis, MO, USA), cells were incubated at $37^{\circ} \mathrm{C}$ for $4 \mathrm{~h}$. After adding $100 \mu \mathrm{l}$ of $10 \%$ SDS-5\% isopropanol$0.012 \mathrm{M} \mathrm{HCl}$, the cells were left overnight at $37^{\circ} \mathrm{C}$. The absorbance of each well was measured at $570 \mathrm{~nm}$ in a Multiscan photometer ( $\mu$ Quant; BioTek, USA). After 2 
days of incubation with different concentrations of HJC, the cells were analyzed using a light microscope BX 41 (Olympus Corporation, Tokyo) with the magnification factor of 400 .

\section{Measurement of SOD activity}

Superoxide anion $\left(\mathrm{O}_{2}^{-}\right)$was generated as a mixture of the enzyme xanthine oxidase and its substrate xanthine. Enzymatic formation of superoxide anion was detected on the basis of cytochrome $c$ reduction by xanthine oxidase plus xanthine. The activity of SOD was detected by its ability to reduce cytochrome $c$, which causes an increase in absorbance at $550 \mathrm{~nm}$. K562 cells $\left(1 \times 10^{5}\right.$ cells $/ \mathrm{ml}$ ) were plated in 96-well plates and allowed to attach for $24 \mathrm{~h}$. HJC was added at different final concentrations that ranged from 8.41 to $135 \mu \mathrm{M}$. After $48 \mathrm{~h}$ of incubation, K562 cells were collected and resuspended in PBS to adjust the cell number to $1 \times 10^{5}$. The cell suspension was treated for three freeze-thaw cycles (thawed from the temperature of $-80^{\circ} \mathrm{C}$ by bringing them to room temperature), and the supernatant was collected to measure the intracellular SOD activity at $550 \mathrm{~nm}$ by using an automatic microplate reader.

\section{Intracellular ROS quantification}

The level of intracellular reactive oxygen species (ROS) was determined by the change of fluorescent probe dichlorofluorescein diacetate (DCFH-DA). Briefly, $1 \times 10^{5} \mathrm{~K} 562$ cells were cultured into Petri dishes and then treated with the indicated concentrations of HJC (8.41, 33.7, and $135 \mu \mathrm{M})$ for $24 \mathrm{~h}$. Cells were washed with PBS and were incubated with $10 \mathrm{mM}$ DCFH-DA for $30 \mathrm{~min}$ at $37^{\circ} \mathrm{C}$. Subsequently, cells were washed 3 times with PBS and ROS level was determined by flow cytometry.

\section{Cell-cycle analysis}

K562 cells were seeded at a density of $1 \times 10^{5}$ cells $/ \mathrm{ml}$ in 12-well plates and incubated with different concentrations of HJC for $48 \mathrm{~h}$. After exposure, $10^{6}$ cells were harvested, washed with ice-cold PBS twice, centrifuged, resuspended, and fixed with $70 \%$ ethanol overnight at $4^{\circ} \mathrm{C}$. Then the fixed cells were washed and resuspended with PBS again, treated with $100 \mu \mathrm{l}$ of $100 \mu \mathrm{g} / \mathrm{ml}$ RNase at room temperature for $10 \mathrm{~min}$, and stained with $200 \mu \mathrm{l}$ of $100 \mu \mathrm{g} / \mathrm{ml}$ PI for $20 \mathrm{~min}$ in the dark. PI-stained cells were assayed using FACS Canto Becton Dickinson Flow Cytometry and cell cycle distributions were analyzed with the ModFit program. All of the samples were assayed in triplicate, and the fraction of every cell cycle phase was calculated.
Annexin V/PI staining and flow cytometry analysis

Apoptosis is a normal physiologic process that occurs during embryonic development as well as in maintenance of tissue homeostasis. In apoptotic cells, the membrane phospholipid phosphatidylserine (PS) is translocated from the inner to the outer leaflet of the plasma membrane, thereby exposing PS to the external cellular environment. Annexin V is a $35-36-\mathrm{kDa} \mathrm{Ca}^{2+}$-dependent phospholipid-binding protein that has a high affinity for PS and binds to cells with exposed PS. Annexin V may be conjugated to fluorochromes including FITC. This format retains its high affinity for PS and thus serves as a sensitive probe for flow cytometric analysis of cells that are undergoing apoptosis.

K562 cells were plated in 12-well plates at a density of $5 \times 10^{5}$ cells per well. The cells were treated with or without varying concentrations $(0,8.41,33.7$, and $135 \mu \mathrm{M})$ of $\mathrm{HJC}$ in complete medium for $48 \mathrm{~h}$. At the end of each treatment, cells were collected and quantitative apoptotic death assay was performed by Annexin V and PI staining (Molecular Probes) following the manufacturer's protocol, and apoptotic cells were then analyzed immediately by flow cytometry using the FACS (BD Pharmingen).

\section{Caspase-3 activity assay}

The caspase-3 enzymatic activity was measured using the caspase- 3 activity assay kits (BioVision, San Francisco, CA, USA) according to the manufacturer's instructions. In brief, cells were seeded at a density of $5 \times 10^{5}$ cells $/ \mathrm{ml}$ in 12 -well slides. After treating with or without varying concentrations $(0,8.41,33.7$, and 135 $\mu \mathrm{M})$ of HJC for $12 \mathrm{~h}$, cells were collected and washed twice with ice-cold PBS and then resuspended in BD Cytofix/Cytoperm ${ }^{\mathrm{TM}}$ solution at a concentration of $1 \times 10^{5}$ cells / $50 \mu \mathrm{l}$. The cells were incubated for $20 \mathrm{~min}$ on ice and then washed twice with Perm/Wash ${ }^{\mathrm{TM}}$ buffer at a volume of $0.5 \mathrm{ml}$ buffer $/ 1 \times 10^{6}$ cells at room temperature. The resuspended cells above were incubated at a concentration of $20 \mu \mathrm{l}$ antibody / $1 \times 10^{6}$ cells for 30 min at room temperature. After that, each test was washed in $1.0 \mathrm{ml} \mathrm{Perm} / \mathrm{Wash}^{\mathrm{TM}}$ buffer and then resuspended in $0.5 \mathrm{ml} \mathrm{Perm} / \mathrm{Wash}^{\mathrm{TM}}$ buffer and analyzed by FACS.

\section{Statistical analysis}

All experimental data are shown as means \pm S.D. and accompanied by the number of experiments. Analysis was performed using one-way ANOVA followed by Dunnett's post-hoc test, and the significant difference was set at $* P<0.05, * * P<0.01$. 


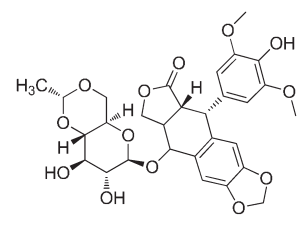

ETO

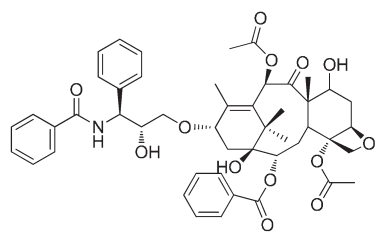

TAX

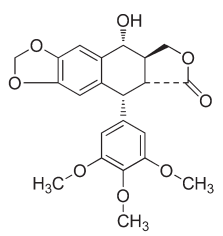

POD

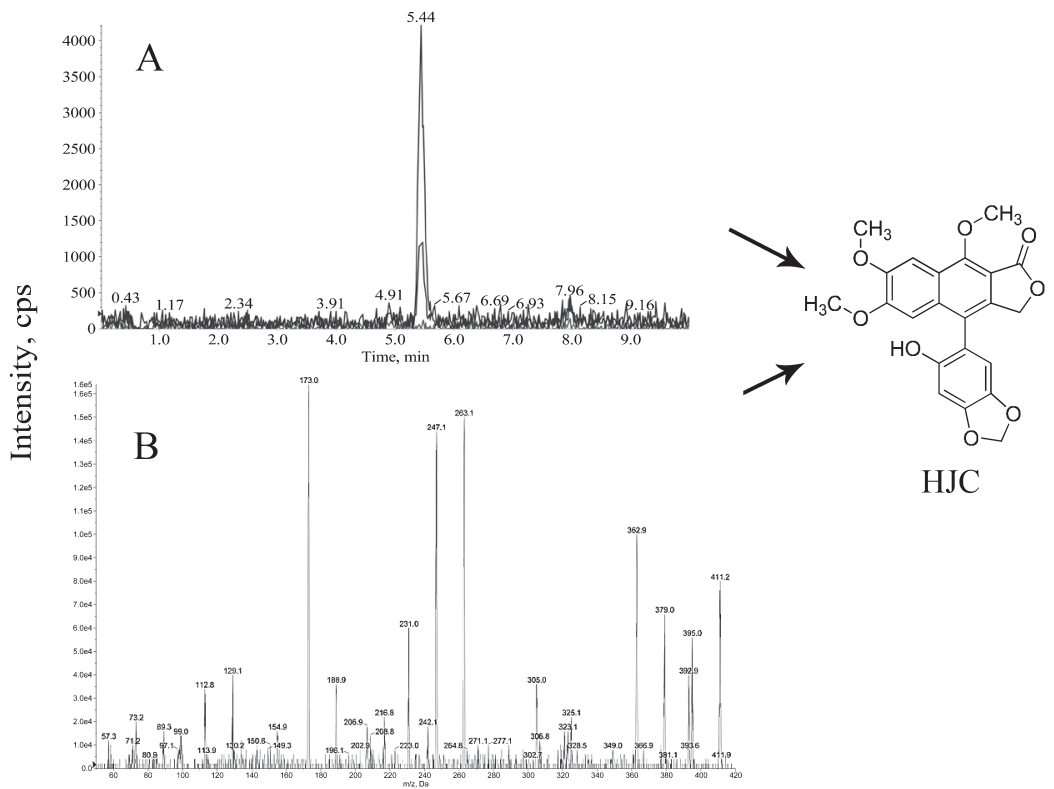

Fig. 1. Chemical structure of 6'-hydroxy justicidin C (HJC), etoposide (ETO), paclitaxel (TAX), and podophyllotoxin (POD). A) typical chromatograms of HJC; B) full-scan product ion spectra of $[\mathrm{M}+\mathrm{H}]^{+}$ions and fragmentation schemes for HJC.

\section{Results}

\section{MRM-IDA-EPI validation of HJC}

As shown in Fig. 1, A and B, no interferences from endogenous substances were observed at the retention times of $5.44 \mathrm{~min}$. EPI scan showed that the main fragment ions were 112.8, 129.1, 173.0, 231.0, 247.1, 263.1, $305.0,362.9,379.0$, and 395.0. This study successfully determined the antitumor component HJC and further authenticated its chemical structure.

\section{HJC inhibits the growth of leukemia K562 cells}

Initially, the cytotoxicity of $\mathrm{HJC}$ was investigated with different doses of HJC $(0.13,0.26,0.53,1.05,2.11,4.22$, $8.4116 .9,33.7,67.5$, and $135 \mu \mathrm{M})$ in human leukemia K562 cells by MTT assay. As shown in Fig. 2B, HJC inhibited the viability of K562 cells in a dose-dependent manner. The results show that after HJC treatment for $48 \mathrm{~h}$, the $50 \%$ inhibition concentration of HJC by MTT assay was $15.2 \mu \mathrm{M}$. Accordingly, the concentrations of HJC used in the following study were 8.41, 33.7, and $135 \mu \mathrm{M}$. The loss of mitochondrial transmembrane potential is a critical step in the process of apoptosis. Typical morphological features of apoptosis, such as cell surface blebbing, were observed under light microscopic examination of K562 cells treated for 2 days with 8.41 $\mu \mathrm{M}$ of HJC. Necrotic cells were detected under light microscopic examination of $\mathrm{K} 562$ cells treated for 2 days with 33.7 and $135 \mu \mathrm{M}$ of HJC (Fig. 2A).

Comparison of the effects of HJA and HJC on K562, HL-60, L1210, and P388D1 cells

To compare the activity between HJC and HJA, the cytotoxicity of the 2 compounds, derived from $J$. procumbens, was investigated in K562, HL-60, L1210, and P388D1 cell lines. After incubation for 2 days, the inhibition ratios of the cells induced by different concentrations of HJC and HJA were delineated (Fig. 3). The results demonstrated that HJC exhibited more cytotoxicity than that of HJA on K562 and HL-60 cell lines, and the $\mathrm{IC}_{50}$ of $\mathrm{HJC}$ on the HL-60 cell line was $20.1 \pm 2.3$ $\mu \mathrm{M}$. In contrast, HJA exhibited more cytotoxicity than that of $\mathrm{HJC}$ on $\mathrm{L} 1210$ and P388D1 cell lines, and the $\mathrm{IC}_{50}$ of HJA on L1210 and P388D1 cell lines were $4.8 \pm 2.4$ and $4.8 \pm 2.4 \mu \mathrm{M}$, respectively.

\section{HJC inhibits the SOD activity of leukemia K562 cells}

Whether HJC can change the redox system in leukemia K562 cells was also examined. Compared with the control, the activity of SOD in human leukemia K562 
A
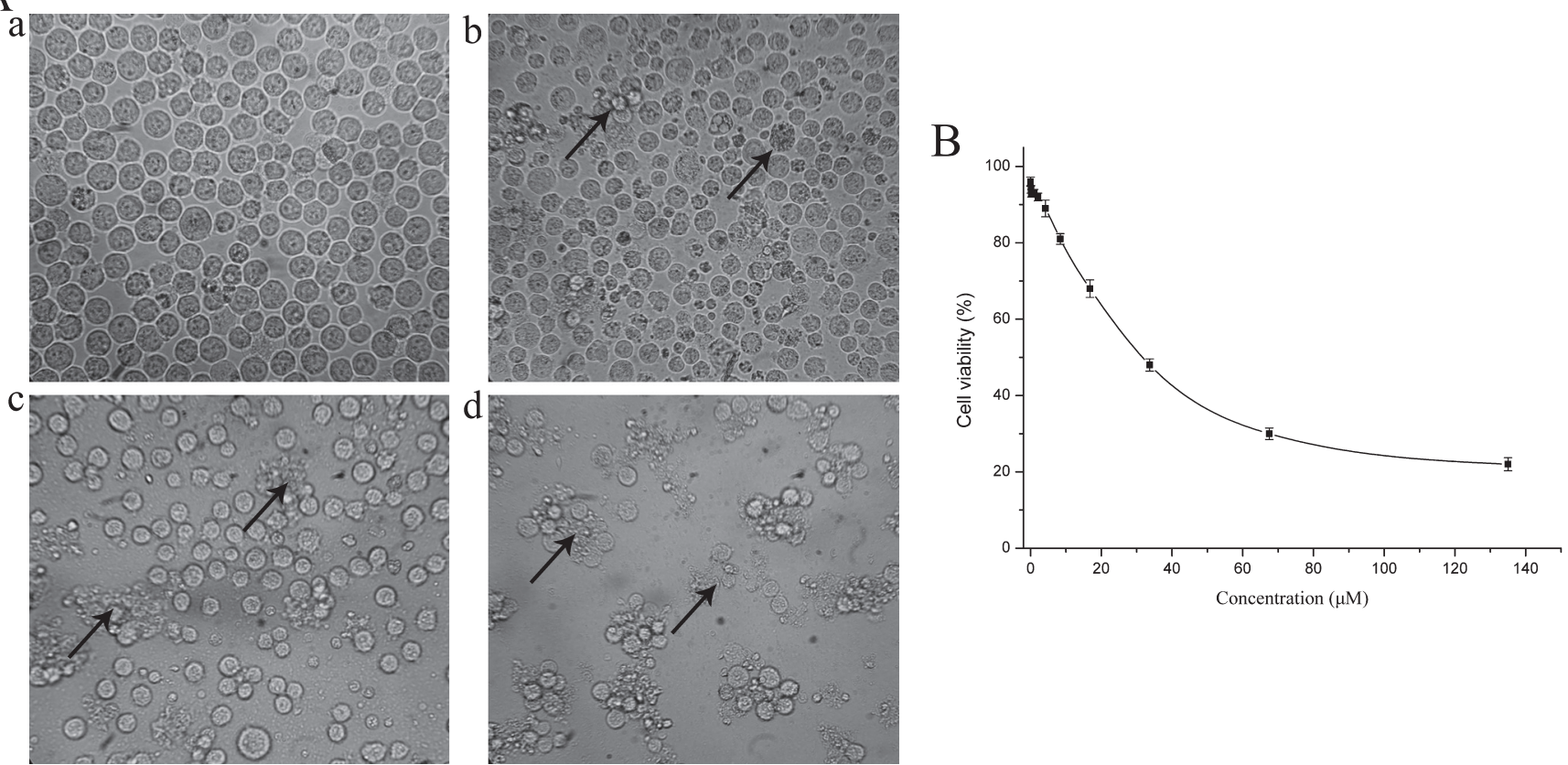

Fig. 2. Growth-inhibitory effect of HJC on the viability of K562 cells evaluated by MTT assay. A) Photomicrographs of K562 cells exposure to different concentrations of HJC for $48 \mathrm{~h}$. a) control group, b) $8.41 \mu \mathrm{M}$ HJC, c) $33.7 \mu \mathrm{M} \mathrm{HJC}$, d) $135 \mu \mathrm{M}$ HJC. B) Effect of HJC on proliferation of K562 cells. The cell viability was determined by the MTT assay. Each data represents the mean \pm S.D. from 3 independent experiments, each at least in triplicate.
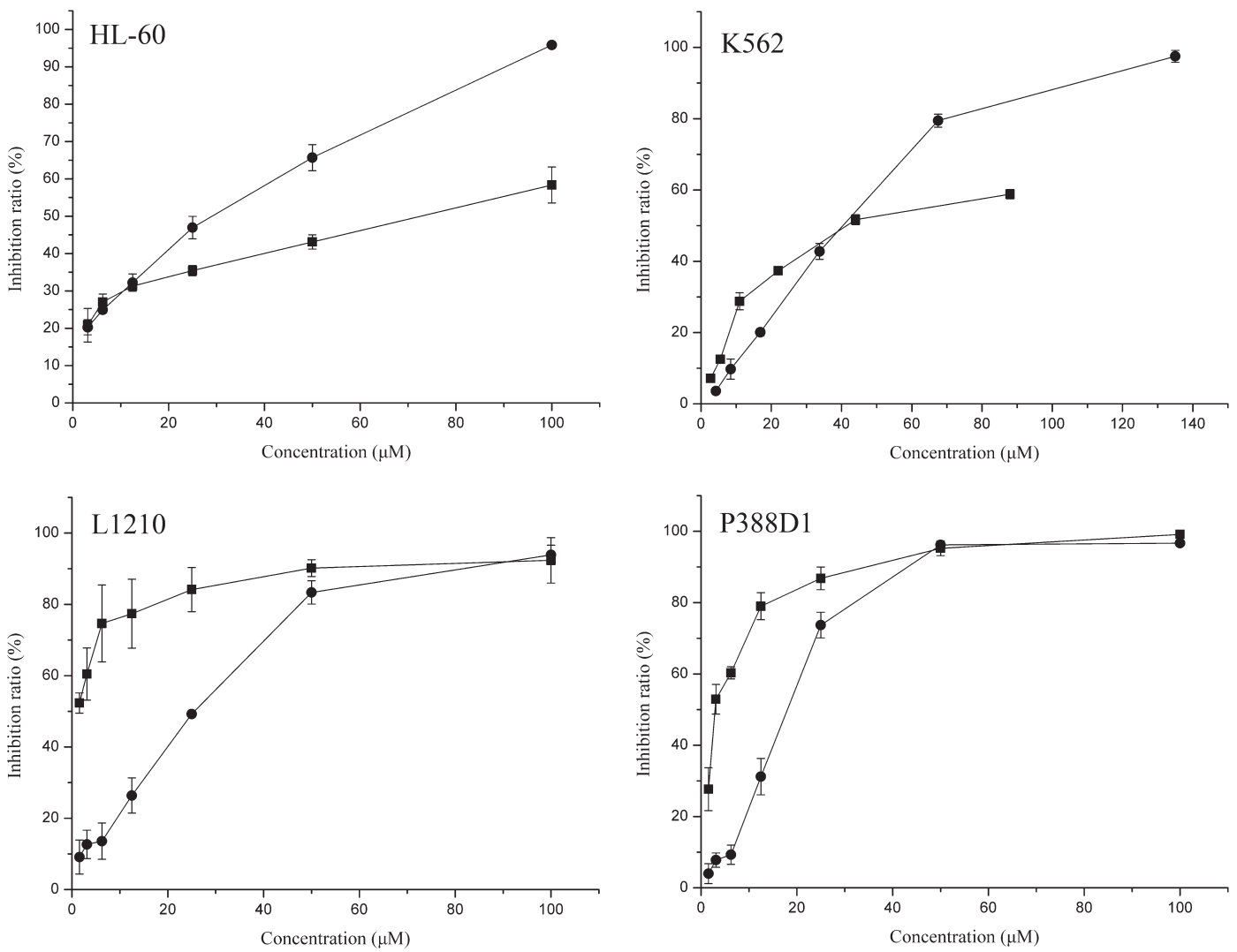

Fig. 3. Comparison of the effects of HJA and HJC on K562, HL-60, L1210, and P388D1 cell lines (the closed circles represent HJC, the closed rectangles represent HJA). The percent of cell inhibition was determined by the MTT assay. The $\mathrm{IC}_{50}$ of $\mathrm{HJC}_{\mathrm{C}}$ HL-60, K562, L1210, and P388D1 was $20.1 \pm 2.3,15.2 \pm 1.2,19.2 \pm 2.1$, and $15.8 \pm 1.9 \mu \mathrm{M}$, respectively; the $\mathrm{IC}_{50}$ of $\mathrm{HJC}_{\mathrm{C}}$ HL-60, K562, L1210, and P388D1 was 35.6 $\pm 2.8,43.9 \pm 2.9,4.8 \pm 2.4$, and 4.8 $\pm 1.4 \mu \mathrm{M}$, respectively. 

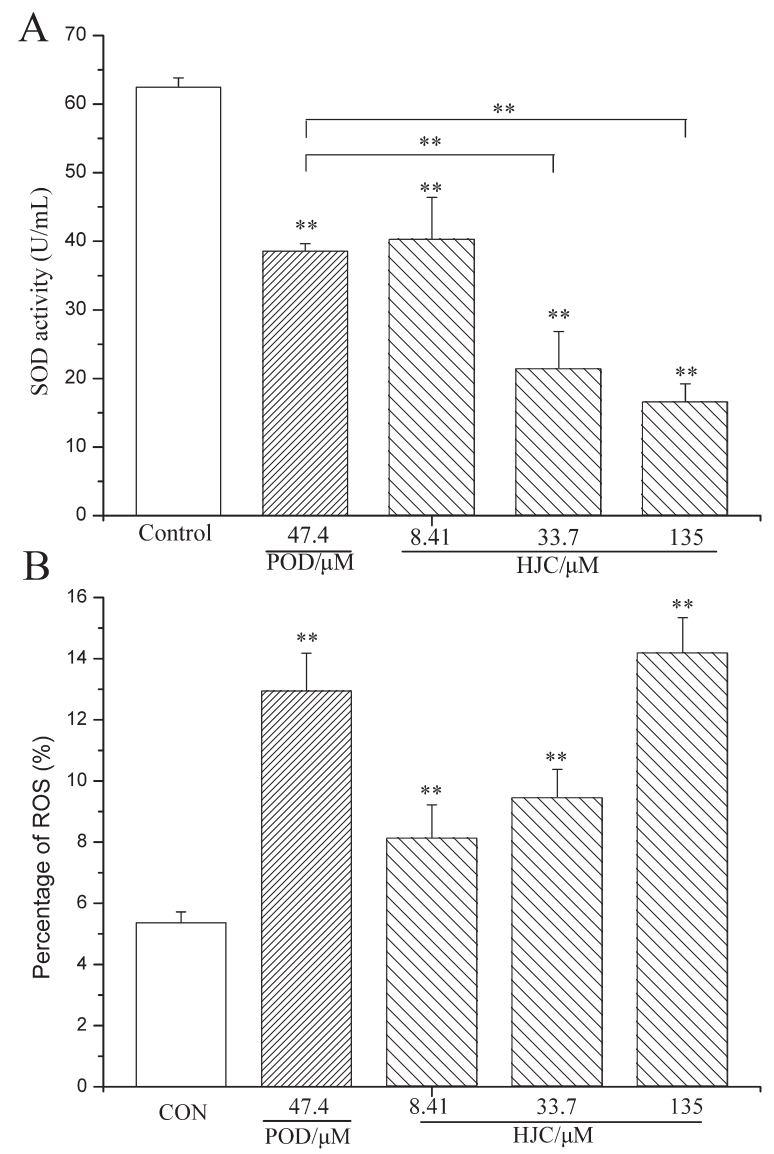

Fig. 4. Effect of HJC on the SOD activity and ROS levels in K562 cells. A) Effect of HJC on SOD activity in K562 cells. K562 cells were treated with different concentrations of HJC and POD for 48 h. B) Intracellular ROS quantification in K562 cells. Values were expressed as the mean \pm S.D. $* * P<0.01$, compared with the control group.

cells decreased remarkably under the increase of HJC concentration (Fig. 4A). Specifically, the activity of SOD decreased $35.6 \%, 65.8 \%$, and $73.5 \%$ at the concentration of $8.41,33.7$, and $135 \mu \mathrm{M}$, respectively.

\section{HJC enhances ROS levels in leukemia K562 cells}

As shown in Fig. 4B, after HJC treatment, the intracellular ROS levels increased remarkably compared with the level in the control group $(P<0.01)$. After $24 \mathrm{~h}$ of incubation with $\mathrm{HJC}$, the fluorescence intensity increased by approximately $260 \%$ as compared with that of the control group.

\section{HJC increased the subG0 phase of K562 cells}

As shown in Fig. 5B, K562 cells treated with $28.5 \mu \mathrm{M}$ POD and $12.0 \mu \mathrm{M}$ TAX for $48 \mathrm{~h}$ were arrested at metaphase phase. At the dose of $28.5 \mu \mathrm{M}$ of POD, the percentage of cells in metaphase phase reached
$94.08 \%$ of total cells compared to $6.99 \%$ in the control group. However, K562 cells treated with $8.41-135 \mu \mathrm{M}$ $\mathrm{HJC}$ and $22.7 \mu \mathrm{M}$ ETO for $48 \mathrm{~h}$ increased the subG0 phase in a dose-dependent manner as higher concentrations of HJC led to significantly higher percentage of cells in the subG0 phase. Cells in G2/M phase were hardly found in this group. The apoptosis percentage of $\mathrm{K} 562$ cells exposed to $8.41,33.7$, and $135 \mu \mathrm{M}$ HJC was $6.35 \%, 14.72 \%$, and $30.52 \%$, respectively (Fig. 5D).

\section{Effect of HJC on apoptosis in K562 cells}

FITC Annexin V staining precedes the loss of membrane integrity, which accompanies the latest stages of cell death resulting from either apoptotic or necrotic processes. Therefore, staining with FITC Annexin $\mathrm{V}$ is typically used in conjunction with a vital dye such as propidium iodide (PI) to allow the investigator to identify early apoptotic cells (PI negative, FITC Annexin V-positive).

The apoptotic death assay employing Annexin V/PI staining followed by FACS analysis clearly showed a dose-dependent apoptotic effect of HJC in K562 cells (Fig. 5A). As shown in the representative FACS analysis scatter-grams, Annexin V/PI staining of control cells showed a large viable cell population with the same staining also for early apoptotic, late apoptotic, and dead cells. However, treatment of cells with HJC at the dose of $8.41,33.7$, or $135 \mu \mathrm{M}$ for $48 \mathrm{~h}$ resulted in a strong shift from live cells to an early and late apoptotic cell population (Fig. 5C). Specifically, the early apoptotic percentage of K562 cells exposed to 8.41, 33.7, and 135 $\mu \mathrm{M}$ HJC was $8.05 \%, 7.99 \%$, and $23.34 \%$, respectively; the viable cell population exposed to $8.41,33.7$, and 135 $\mu \mathrm{M} \mathrm{HJC}$ was $86.86 \%, 85.12 \%$, and $64.70 \%$, respectively. The positive reference drug ETO induced apoptosis at the concentration of $22.7 \mu \mathrm{M}$ (the viable cell population was $72.88 \%$ ), but the apoptosis was not increased when the dose of ETO increased to $90.6 \mu \mathrm{M}$ (the viable cell population was $70.64 \%$ ).

HJC-induced apoptosis is related with a caspasedependent pathway

Active caspase-3, a marker for cells undergoing apoptosis, consists of a heterodimer of $17-$ and $12-\mathrm{kDa}$ subunits, which is derived from the $32-\mathrm{kDa}$ pro-enzyme. FITC Anti-Active Caspase-3 Antibody has been reported to specifically recognize the active form of caspase- 3 in human and mouse cells.

Human leukemia K562 cells were left untreated or treated for $12 \mathrm{~h}$ with $\mathrm{HJC}$ to induce apoptosis. Cells were permeabilized, fixed, and stained for active caspase- 3 as described in the accompanying Staining Protocol. Cells were then analyzed by flow cytometry. As shown in 
A
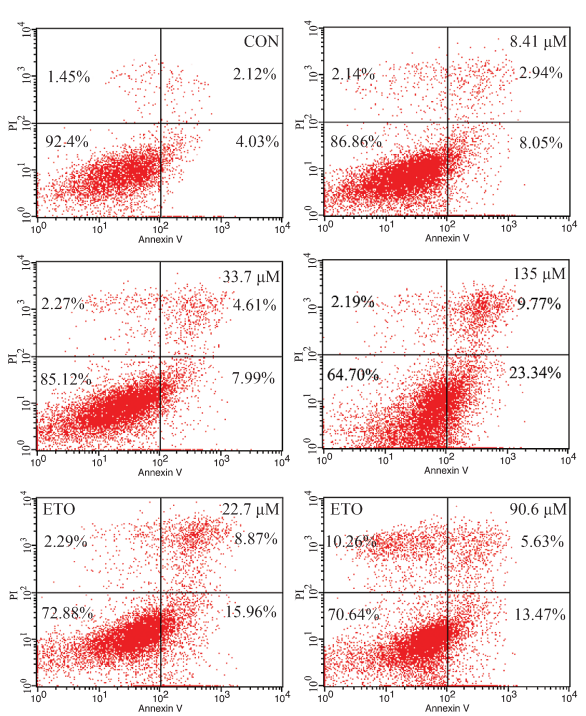

C

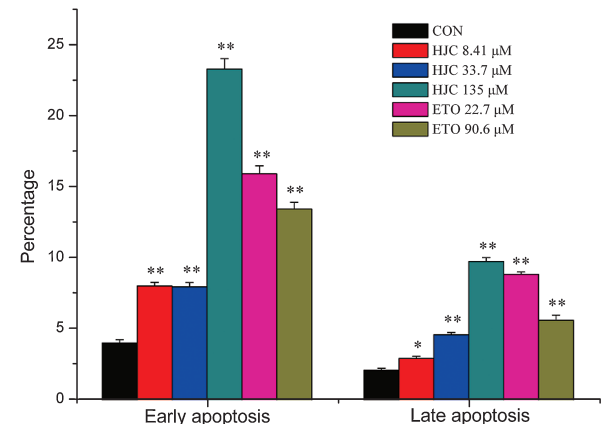

Early apoptosis

Late apoptosis
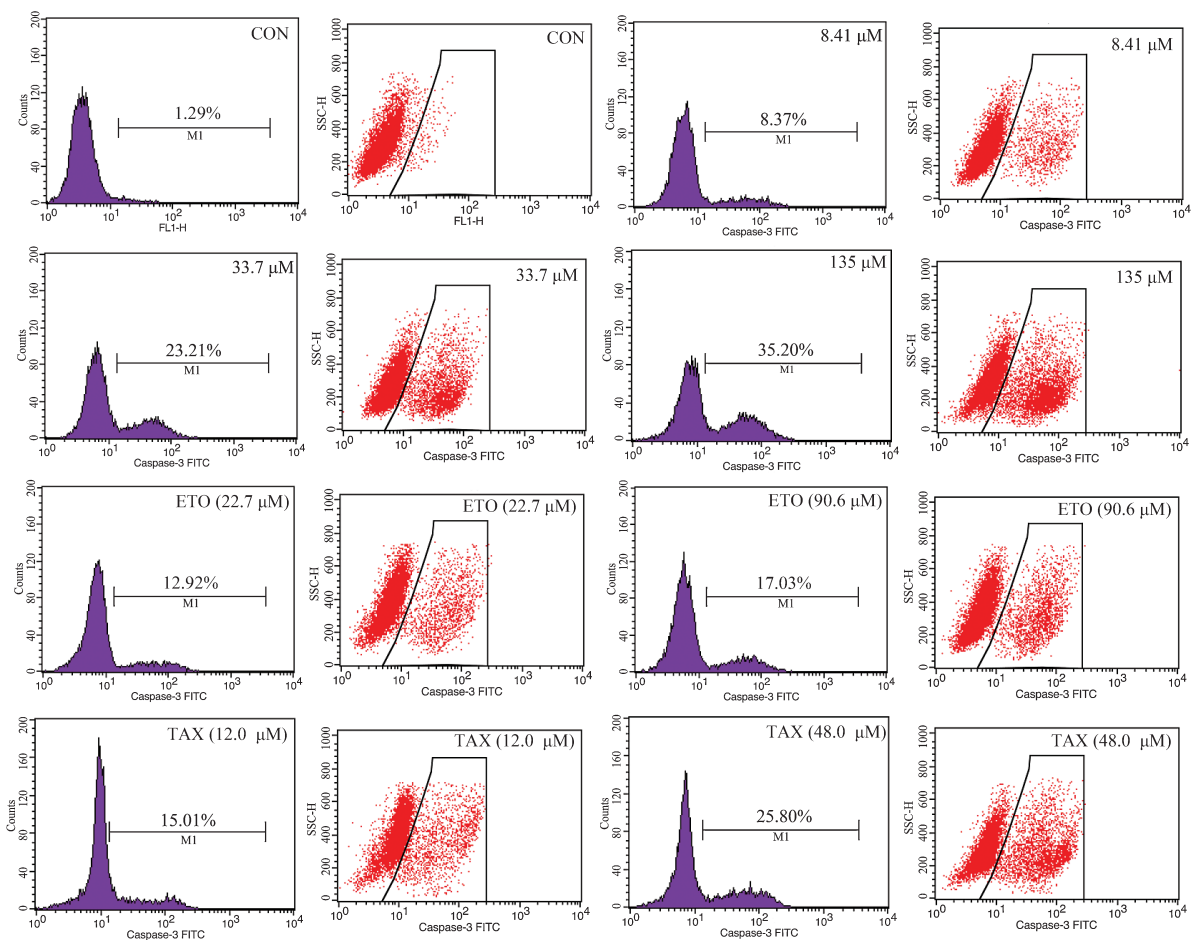
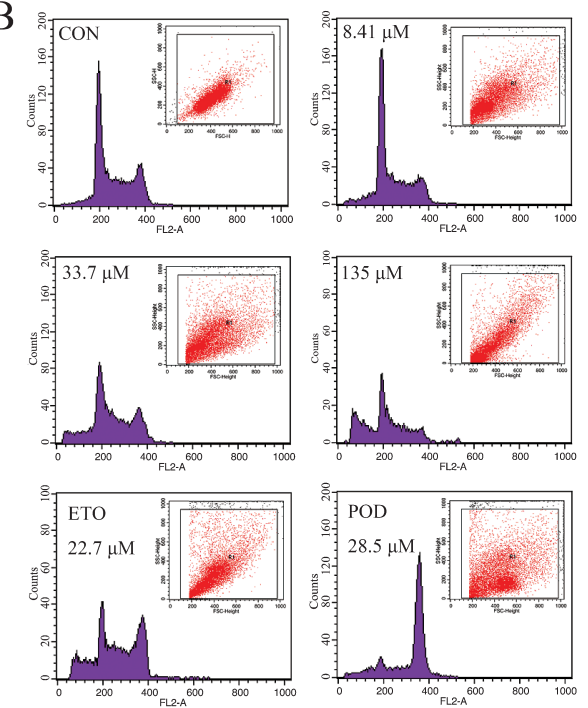

D

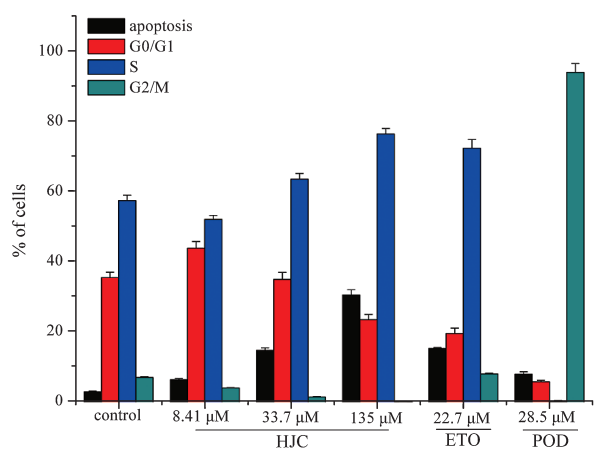

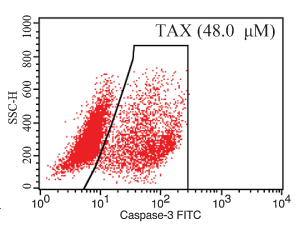

Fig. 5. Effect of HJC on apoptosis in K562 cells by flow cytometry. All the results shown in this figure are representative of 3 experiments with similar results. A) PI analysis of K562 cells treated with different concentrations of HJC for $24 \mathrm{~h}$. B) HJC caused strong apoptotic death of K562 cells. Representative FACS analysis scattergrams of Annexin V/PI-stained control and cells treated with $0,8.41,33.7$, or $135 \mu \mathrm{M} \mathrm{HJC}$ for $48 \mathrm{~h}$ showed 4 different cell populations. C) Statistical analysis of the percentage of early and late apoptosis caused by HJC. D) The apoptosis rate and change of cell cycle of K562 cells treated with HJC for $24 \mathrm{~h}$. Cells were plated in 12-well plates at a density of $1 \times 10^{5}$ cells per well.

Fig. 6. Effects of HJC on caspase-3 activity in K562 cells. The changes of active caspase- 3 were detected by flow cytometry in K562 cells after treatment with $8.41,33.7$, and $135 \mu \mathrm{M} \mathrm{HJC}$ for $48 \mathrm{~h}$. 
Fig. 6, the positive control, ETO and TAX induced apoptosis at different concentrations. For example, while untreated cells were primarily negative $(1.29 \%)$ for active caspase- 3 , treatment with 12.0 and $48.0 \mu \mathrm{M}$ TAX increased the percentages of active caspase-3 positive cells to $15.01 \%$ and $25.80 \%$, respectively. Similarly, HJC treatment induced apoptosis in K562 cells in a dose-dependent manner. The percentage of active caspase-3-positive cells were increased 8.37\%, 23.21\%, and $35.20 \%$ when treated with $8.41,33.7,135 \mu \mathrm{M}$ HJC.

\section{Discussion}

HJC is a new compound extracted from the $J$. procumbens plants and has been identified to have a basic molecular structure similar to that of the classic antitumor drug POD. Previous study showed that the content of HJC in J. procumbens was lower than those in JB, CME, HJB, and HJA (24). However, our research showed that the $\mathrm{IC}_{50}$ of $\mathrm{HJC}$ on $\mathrm{K} 562$ and HL-60 cell lines was lower than that of HJA (Fig. 3), which indicated that the change in the binding position of the oxygen would influence the cytotoxicity to specific tumor cells. In addition, our ongoing study indicated that the oral absolute bioavailability of HJC was higher than that of HJA (25) $(36.0 \% \pm 13.4 \%)$ and CME (26) $(3.2 \% \pm 0.2 \%)$, making HJC a promising candidate for leukemia therapy. Furthermore, HJC was shown to induce apoptosis in human leukemia K562 cells for the first time, and this effect involves caspase activation.

Mitochondria are responsible for generation of substantial amounts of superoxide caused by electron leakage from the oxidative phosphorylation pathway. SOD is the first line of defense against ROS, protectingt cells from the peroxidation injury induced by transferring one radical $\left(\mathrm{O}_{2}^{-}\right)$to the next $\left(\mathrm{H}_{2} \mathrm{O}_{2}\right)(27)$. In this study, the activity of SOD was decreased significantly in K562 cells after the treatment of HJC. Analysis of ROS content and mitochondrial transmembrane potential $(\Delta \psi \mathrm{m})$, using specific fluorescent probes in flow cytometry, showed that HJC can mediate ROS production and the loss of $\Delta \psi \mathrm{m}$.

ETO, a topoisomerase II inhibitor, is extensively used in the treatment of leukemia. However, K562 cells are known to be less sensitive to ETO than other cell lines (28). Jiang et al. used flow cytometry to measure the apoptosis rate induced by continuous exposure to ETO $(10 \mu \mathrm{M})$ in $\mathrm{K} 562$ cells and found that apoptosis was barely detected $24 \mathrm{~h}$ after exposure to ETO (29). In this study, the cytotoxicity of POD and ETO were not significant when the concentration was less than $20 \mu \mathrm{M}$. In addition, when the concentration of ETO was 90.6 $\mu \mathrm{M}$, both the early and late apoptosis percentages detected were lower than that of $135 \mu \mathrm{M} \mathrm{HJC}$.

The inhibition of cancer cell proliferation and induction of apoptosis are important mechanisms for a chemotherapeutic agent (30). A number of proteins are known to be involved in the regulation of apoptosis through the mitochondrial pathway and in turn promote activation of the downstream molecules in the caspase cascade, such as the Bcl-2 family proteins (31).

Caspases are a family of cysteine proteases that cleave target proteins at specific aspartate residues, constituting key components of the apoptotic pathway. Two distinct pathways of apoptosis have been identified: mitochondria-initiated apoptosis that occurs through caspase-9 and the death receptor-mediated pathway that requires caspase-8 (32). Caspase-3 is a key effecter molecule in the caspase-dependent cell apoptosis pathway that cleaves a number of cellular proteins, leading to apoptotic changes. Thus activation of the enzymatic activity of caspases-3 might provide a mechanism to initiate the apoptotic program (33). In this study, HJC treatment induced apoptosis in K562 cells in a dose-dependent manner. The activity of $33.7 \mu \mathrm{M}$ HJC was equal to that of $48.0 \mu \mathrm{M}$ TAX and stronger than that of $90.6 \mu \mathrm{M}$ ETO.

Our results indicated that HJC raised the enzymatic activity of caspase- 3 significantly. We concluded that HJC-induced apoptosis in K562 cells via the activation of caspase-dependent pathway through the caspase-3 mitochondrial pathway. This study presents a potential novel alternative to human leukemia K562 cell therapy.

\section{Acknowledgments}

Financial support for this work from the Beijing Natural Science Foundation of China (7112092), Program for PUMC Innovative Foundation, and Specialized Research Fund for the Doctoral Program of Higher Education (20111106110034) is gratefully acknowledged.

\section{References}

1 MacRae WD, Towers GHN. Biological activities of lignans. Phytochemistry. 1984;23:1207-1220.

2 Jardine I. In: Cassady JM, Douros J, editors. Anticancer agents based on natural product models. New York: Academic Press; 1980. p. 319-351.

3 Lee KH, Beers SA, Mori M, Wang ZQ, Kuo YH, Li L, et al. Antitumor agents. 111. New 4-hydroxylated and 4-halogenated anilino derivatives of 4'-demethylepipodophyllotoxin as potent inhibitors of human DNA topoisomerase II. J Med Chem. 1990;33:1364-1368.

4 Lee SY, Cho JS, Yuk DY, Moon DC, Jung JK, Yoo HS, et al. Obovatol enhances docetaxel-induced prostate and colon cancer cell death through inactivation of nuclear transcription factor- $\kappa \mathrm{B}$. J Pharmacol Sci. 2009;111:124-136.

5 Ayres DC, Loike JD. Lignans: chemical, biological, and clinical properties. Cambridge, New York: Cambridge University Press; 
1990.

6 Schacter L. Etoposide phosphate: what, why, where, and how? Semin Oncol. 1996;23:1-7.

7 Gordaliza M, Castro MA, del Corral JM, Feliciano AS. Antitumor properties of podophyllotoxin and related compounds. Curr Pharm Des. 2000;6:1811-1839.

8 You Y. Podophyllotoxin derivatives: current synthetic approaches for new anticancer agents. Curr Pharm Des. 2005;11:1695-1717.

9 Su CL, Huang LL, Huang LM, Lee JC, Lin CN, Won SJ. Caspase- 8 acts as a key upstream executor of mitochondria during justicidin A-induced apoptosis in human hepatoma cells. FEBS Lett. 2006;580:3185-3191.

10 Day SH, Lin YC, Tsai ML, Tsao LT, Ko HH, Chung MI, et al. Potent cytotoxic lignans from Justicia procumbens and their effects on nitric oxide and tumor necrosis factor-alpha production in mouse macrophages. J Nat Prod. 2002;65:379-381.

11 Fukamiya N, Lee KH. Antitumor agents, 81. Justicidin-A and diphyllin, two cytotoxic principles from Justicia procumbens. J Nat Prod. 1986;49:348-350.

12 Yang $\mathrm{M}, \mathrm{Wu}$ J, Cheng F, Zhou Y. Complete assignments of ${ }^{1} \mathrm{H}$ and ${ }^{13} \mathrm{C}$ NMR data for seven arylnaphthalide lignans from Justicia procumbens. Magn Reson Chem. 2006;44:727-730.

13 Zhang P, Dong XZ, Zhou YT, Yang MH, Bi MG. [Mechanism of JR6 to induce human bladder cancer EJ cells apoptosis]. Chin Pharmacol Bull. 2009;25:173-174. (text in Chinese with English abstract)

14 Zhang P, Zhou WQ, Dong XZ, Yang MH, Bi MG. [Effect of 6'-hydroxy justicidin A on cell proliferation and redox system in tumor cells]. Chin J Pharmacol Toxicol. 2010;24:207-213. (text in Chinese with English abstract)

15 Deng JY, Yang MH, Bi MG. [In vitro anti-tumor mechanism of JR6 on human colon cancer cell HT-29]. Chin Pharmacol Bull. 2009;25:190-191. (text in Chinese with English abstract)

16 Di Giorgio C, Delmas F, Akhmedjanova V, Ollivier E, Bessonova I, Riad E, et al. In vitro antileishmanial activity of diphyllin isolated from Haplophyllum bucharicum. Planta Med. 2005; 71:366-369.

17 Chen CC, Hsin WC, Ko FN, Huang YL, Ou JC, Teng CM. Antiplatelet arylnaphthalide lignans from Justicia procumbens. J Nat Prod. 1996;59:1149-1150.

18 Asano J, Chiba K, Tada M, Yoshii T. Antiviral activity of lignans and their glycosides from Justicia procumbens. Phytochemistry. 1996;42:713-717.

19 Green DR, Reed JC. Mitochondria and apoptosis. Science. 1998;281:1309-1312.

20 Yamada Y, Nakamura K, Furukawa R, Kawamura E, Moriwaki
T, Matsumoto K, et al. Mitochondrial delivery of bongkrekic acid using a MITO-Porter prevents the induction of apoptosis in human HeLa cells. J Pharmacol Sci. 2013;102:1008-1015.

21 Roth W, Reed JC. Apoptosis and cancer: When BAX is TRAILing away. Nat Med. 2002;8:216-218.

22 Yang M, Wu J, Xu X, Jin Y, Guo Y, Chen J. A new lignan from the Jian-er syrup and its content determination by RP-HPLC. J Pharm Biomed Anal. 2006b;41:662-666.

$23 \mathrm{Wu} \mathrm{SJ}, \mathrm{Wu}$ TS. Cytotoxic arylnaphthalene lignans from Phyllanthus oligospermus. Chem Pharm Bull (Tokyo). 2006; 54:1223-1225.

24 Luo Z, Kong W, Qiu F, Yang M, Li Q, Wei R, et al. Simultaneous determination of seven lignans in Justicia procumbens by high performance liquid chromatography-photodiode array detection using relative response factors. J Sep Sci. 2013;36:699-705.

25 Qiu F, Zhou S, Fu S, Kong W, Yang S, Yang M. LC-ESI-MS/MS analysis and pharmacokinetics of 6'-hydroxy justicidin A, a potential antitumor active component isolated from Justicia procumbens, in rats. J Pharm Biomed Anal. 2012;70:539-543.

26 Zhou S, Qiu F, Tong Z, Yang S, Yang M. Application of a sensitive and specific LC-MS/MS method for determination of chinensinaphthol methyl ether in rat plasma for a bioavailability study. J Chromatogr B Analyt Technol Biomed Life Sci. 2012; 903:75-80.

27 Bechtel W, Bauer G. Modulation of intercellular ROS signaling of human tumor cells. Anticancer Res. 2009;29:4559-4570.

28 McGahon A, Bissonnette R, Schmitt M, Cotter KM, Green DR, Cotter TG. BCR-ABL maintains resistance of chronic myelogenous leukemia cells to apoptotic cell death. Blood. 1994; 83:1179-1187.

29 Jiang H, Hou C, Zhang S, Xie H, Zhou W, Jin Q, et al. Matrine upregulates the cell cycle protein E2F-1 and triggers apoptosis via the mitochondrial pathway in K562 cells. Eur J Pharmacol. 2007;559:98-108.

30 Hanahan D, Weinberg RA. The hallmarks of cancer. Cell. 2000;100:57-70.

31 Norbury CJ, Zhivotovsky B. DNA damage-induced apoptosis. Oncogene. 2004;23:2797-2808.

32 Mao WP, Ye JL, Guan ZB, Zhao JM, Zhang C, Zhang NN, et al. Cadmium induces apoptosis in human embryonic kidney (HEK) 293 cells by caspase-dependent and -independent pathways acting on mitochondria. Toxicol In Vitro. 2007;21:343-354.

33 Potokar M, Milisav I, Kreft M, Stenovec M, Zorec R. Apoptosis triggered redistribution of caspase- 9 from cytoplasm to mitochondria. FEBS Lett. 2003;544:153-159. 